\title{
Application of widely used fungicides does not necessarily affect grain yield, and incidence of Fusarium spp. and mycotoxins DON, HT-2 and T-2 in spring barley in northern climates
}

\author{
Elina Karron ${ }^{1 \dagger}$, Eve Runno-Paurson ${ }^{3^{*}+}$, Heino Lõiveke ${ }^{2 * *}$, Bulat Islamov ${ }^{2}$, Mary-Liis Kütt ${ }^{4}$, Tiina Talve ${ }^{1}$, \\ Enn Lauringson ${ }^{3}$, Hanna Hõrak ${ }^{3}$, Liina Edesi ${ }^{1}$, Ülo Niinemets ${ }^{3}$ \\ Department of Agrotechnology, Estonian Crop Research \\ Institute, J. Aamisepa 1, 48309, Jõgeva, Estonia \\ 2 Department of Plant Protection, Estonian Crop Research \\ Institute, J. Aamisepa 1, 48309, Jõgeva, Estonia \\ 3 Chair of Crop Science and Plant Biology, Institute of Agricultural \\ and Environmental Sciences, Estonian University of Life \\ Sciences, Kreutzwaldi 5, 51006 Tartu, Estonia \\ 4 Institute of Technology, University of Tartu, Nooruse 1, \\ Tartu 50411, Estonia \\ *corresponding e-mail: eve.runno-paurson@emu.ee \\ †Equal contribution as first co-author \\ **in memoriam
}

\begin{abstract}
Fungicides are widely used to reduce Fusarium infections and grain contamination by mycotoxins and increase the yield in cereals, but the efficacy of fungicide treatments in varying climates has not been systematically explored. Field experiments with Estonian spring barley (Hordeum vulgare L.) cv. 'Maali' were carried out in three successive years 2012-2014 with strongly varying weather conditions to study the effects of three fungicides, Folicur (active ingredient tebuconazole), Falcon Forte (prothioconazole, tebuconazole, spiroxamine) and Archer Top (fenpropidin, propiconazole), on the yield, incidence of Fusarium spp. and on the contamination of grain with mycotoxins DON, HT-2 and T-2. The fungicides were sprayed once a year at spring barley flowering time. The weather conditions during the three years of study were extremely different. The content of mycotoxin DON, HT2 and T2 was low. The spraying with fungicides had not a clear effect on the barley yield and 1000 kernel weight, and the study year was primarily the main factor that affected barley yield $(p<0.05)$ and 1000 kernel weight $(p<0.05)$. The impact of year together with fungicide treatment had a significant effect on the incidence of Fusarium spp. $(p<0.05)$ and on the incidence of mycotoxin DON in barley kernels $(p<0.001)$, but did not have a clear effect on the incidence of mycotoxins $\mathrm{HT} 2$ and $\mathrm{T} 2$.
\end{abstract}

Key words: spring cereal, pesticide, moulds, trichothecenes

\section{Introduction}

Spring barley is the most widely grown spring cereal crop in Estonia. In 2016-2018 the spring barley growing area was $36 \%$ of all cereal crops growing area and $56 \%$ of the spring cereals area (Statistics Estonia, 2019). Spring barley for Estonia is an economically important crop since, in 2006, 63\% of barley grain was exported. In 2016 in Esto- nia, 36\% spring barley was used as animal feed, $5 \%$ as seed and $0.3 \%$ of barley was used for human consumption (Statistics Estonia, 2016). On average, 2\% of globally produced barley is used directly as human food, $25 \%$ is used for malting and brewery industry and the main part of the barley is used for animal feed (Baik and Ullrich, 2008). In spring 
barley, the Fusarium Link ex Fr. causes worldwide disease and grain contamination with mycotoxins (Parikka et al., 2012; Nielsen et al., 2014; Horky et al., 2018). In Northern Europe, the Fusarium head blight (FHB) caused mainly by F. graminearum sensu stricto, F. culmorum, F. poae, F. sporotrichioides, F. langsethiae, F. tricinctum and F. avenaceum, reduces grain quality and the usefulness of grain for food and feed purposes by producing a variety of mycotoxins, of which most common are deoxynivalenol (DON), T-2, HT-2 and nivalenol (NIV) (Yli-Mattila et al., 2011, 2013; Hietaniemi et al., 2016). In earlier studies in Estonia it was found that Fusarium spp. were present in $79 \%$ of feed barley samples and on average $29 \%$ of spring barley grains were contaminated with Fusarium spp. Dominant species identified in spring barley grains were $F$ avenaceum, F. sporotrichioides, F. poae, F. oxysporum, F. solani and F. culmorum (Lõiveke et al., 2003). In 2006 and 2007, mycotoxins were present in $41 \%$ and $66 \%$ of feed cereal samples respectively, and it was demonstrated that the mould count and the occurrence of Fusarium spp. increases with increasing total precipitation and precipitation frequency during the flowering and pre-harvest time of the cereals (Lõiveke et al., 2008). Field trials with wheat showed that the use of the fungicides in moist and wet vegetation period decreased the count of moulds and Fusarium spp. in grain (Lõiveke, 2004). The results of the study confirmed that Estonian climatic conditions are favourable for mycotoxin production in cereals during vegetation period, but no correlation was found between the mould count, Fusarium spp. count and accumulation of mycotoxins (Lõiveke, 2004). The use of chemical control measures such as fungicide spray at cereal anthesis stage has been well investigated and is recommended for prevention of mycotoxin accumulation in grain (Wegulo et al., 2015). Lõiveke et al. (2004) investigated the effect of 14 different fungicides on the incidence of Fusarium fungi in winter wheat (Triticum aestivum) grain. The authors found that the fungicide containing a combination of active ingredients fenpropimorph, prochloraze and propiconazole decreased the incidence of Fusarium spp. in $75-100 \%$ of winter wheat kernels. Additionally, Sooväli et al. (2017) investigated the effect of barley seed treatment by fungicides containing various active ingredients. In greenhouse trials it was found that seed treatment before sowing of spring barley with different fungicide preparations containing tebuconazole alone, commercial mixtures of triticonazole and prochlorazole, fludioxonil and cyproconazole, fludioxonil and difenoconazole did not reduce the count of seed-borne inoculum of Fusarium spp. However, the active ingredients of triazole group of fungicides containing a combination of protioconazole and tebuconazole were most effective against the Fusarium fungi (Sooväli et al., 2017).
Studies conducted in Europe, Scandinavia and North America showed that the mycotoxin DON was present in 58-91\%, mycotoxin T-2 in 50-61\% and its deacetylated form mycotoxin HT- 2 in $12-50 \%$ of barley grain samples. Thus, the mycotoxin DON is the most common toxin in barley samples (Petterson, 1996; Perkowski et al., 2003). Fungicide treatments to protect barley against Fusarium spp. and reduce mycotoxin accumulation in field conditions have resulted in controversial outcomes. In the Baltic region, attempts to control infestation of spring barley grains by mycotoxins have been carried out in Lithuania in a two-year study (Semaškiene et al., 2006), but the experiments were conducted in relatively warm and dry conditions, and there is no information about the efficacy of key fungicides in cooler and more humid climates further north. The aim of the present study was to investigate the impact of fungicide treatment: 1) on the yield and 1000 kernel weight of spring barley, 2) on the incidence of Fusarium spp., to identify the effect of pure and mixed active ingredients of commercial fungicides on the production of the toxins DON, HT-2 and T- 2 in the spring barley grain in field experiments. Additionally, the results of the current study allow to provide practical recommendations for farmers to reduce Fusarium spp. infection and mycotoxins infestation of barley grains.

\section{Materials and methods}

The field trials were carried out in 2012-2014 at the Estonian Crop Research Institute experimental area in Kõbu $\left(59^{\circ} 27^{\prime} \mathrm{N}, 2^{\circ} 63^{\prime} \mathrm{E}\right)$ in North-Estonia. The soil was a sandy loam Gleysol according to WRB classification. The soil chemical analysis was carried out in the Laboratory of Agrochemistry of Agricultural Research Centre. The soil was weakly acid (pH 5.6), with high organic carbon (3.3\%) and total phosphorus (139 $\mathrm{mg} \mathrm{kg}^{-1}$ )content, medium calcium (2271 mg kg-1), magnesium ( $86 \mathrm{mg} \mathrm{kg}^{-1}$ ), copper (1.6 $\mathrm{mg} \mathrm{kg}^{-1}$ ) and boron (1.35 $\mathrm{mg} \mathrm{kg}^{-1}$ ) content, and low potassium (51 mg kg-1) and manganese (57 $\mathrm{mg} \mathrm{kg}^{-1}$ ) content. The experimental area was ploughed each autumn. The field plot size was $25 \mathrm{~m}^{2}$ and the experiments were randomized in four replications. Two row spring barley (Hordeum vulgare L.) Estonian cultivar 'Maali' was used with a seed sowing rate of 550 seeds per $\mathrm{m}^{2}$. The plots were fertilized with a complex mineral fertilizer $15 \mathrm{~N}-15 \mathrm{P}_{2} \mathrm{O}_{5}$ $15 \mathrm{~K}_{2} \mathrm{O}-9 \mathrm{~S}$ (amount $270 \mathrm{~kg} \mathrm{ha}^{-1}$, nitrogen $40 \mathrm{~kg}$, phosphorus $18 \mathrm{~kg}$, potassium $36 \mathrm{~kg}$ and sulphur $24 \mathrm{~kg} \mathrm{ha}^{-1}$ ) at sowing time. Ammonium nitrate ( $60 \mathrm{~kg} \mathrm{ha}^{-1}$ ) was added in the beginning of stem elongation (BBCH 30 ) by top-dressing. The preceding crop was spring wheat. The fungicide treatments were applied as follows: 1) untreated control; 
2) treated with Folicur $1.0 \mathrm{l} \mathrm{ha}^{-1}$, (active ingredient $250 \mathrm{~g} \mathrm{l}^{-1}$ tebuconazole); 3) treated with Falcon Forte $1.0 \mathrm{l} \mathrm{ha}^{-1}$, (active ingredients $53 \mathrm{~g} \mathrm{l}^{-1}$ prothioconazole, $224 \mathrm{~g} \mathrm{l}^{-1}$ spiroxamine, $148 \mathrm{~g} \mathrm{l}^{-1}$ tebuconazole); 4) treated with Archer Top $400 \mathrm{EC} 0.8 \mathrm{l} \mathrm{ha}^{-1}$, (active ingredients $275 \mathrm{~g} \mathrm{l}^{-1}$ fenpropidin and $125 \mathrm{~g} \mathrm{l}^{-1}$ propiconazole). In each case, the fungicides were applied with $300 \mathrm{l} \mathrm{ha}^{-1}$ water. The treatments with fungicides were carried out at flowering time, BBCH 65. For weed control, herbicide MCPA (2-methyl-4-chlorophenoxyacetic acid) was applied at a dose $2.0 \mathrm{l} \mathrm{ha}^{-1}$ in $400 \mathrm{l} \mathrm{ha}^{-1}$ water. No other pesticides were used.

\subsection{Yield and 1000 kernel weight}

Mature spring barley crop was harvested by a combine from each trial plot. The yield of every plot was dried, sorted, weighed and the samples were taken for the analysis of dry matter and 1000 kernel weight. The hectare yield, $Y_{a}\left(\mathrm{~kg} \mathrm{ha}^{-1}\right)$, was calculated as: $Y_{a}=S_{p} D_{s} / A_{p} / 100$ where $S_{p}$ is the plot yield (kg), $A_{p}$ is the plot area (ha), and $D_{s}$ is the standard percentage of dry matter (86\%).

\subsection{Incidence of Fusarium spp.}

$1.5 \mathrm{~kg}$ grain samples were taken from each variant for analysis of the incidence of Fusarium spp. and mycotoxins DON, HT- 2 and T-2 in barley grain. The samples were dried and cleaned from debris and small kernels using a sieve with mesh size of $2 \mathrm{~mm}$. One hundred kernels from each sample were taken. The kernels were cleaned in $1 \%$ sodium hypochlorite, and rinsed twice with distilled water. After drying, the kernels were put in a Petri dish on the Czapek-Dox medium (35 g Czapek-Dox broth, $15 \mathrm{~g}$ agar, $1 \mathrm{ml}$ dichloran, $1 \mathrm{ml}$ tetracycline, and $1000 \mathrm{ml} \mathrm{MQ}$ water). The plates were held under a day-night cycle ( $8 \mathrm{hr}$ light/16 hr dark) at room temperature $\left(20^{\circ} \mathrm{C}\right)$ for seven days, and then the number of the kernels contaminated with Fusarium spp. was counted. The Fusarium isolates from contaminated kernels were cultured on the PDA (potato dextrose agar) in $90 \mathrm{~mm}$ Petri dishes. The second isolation was done after a week in PDA and CLA (carnation leaf-piece agar). After 14 days, the Fusarium species were determined using a light microscope Olympus BX 51 (magnitude 100x) according to Leslie and Summerell (2006).

\subsection{DON, HT-2 and T-2 quantification}

Gas chromatography mass-spectrometry (GC-MS, Agilent 7890A and Agilent 5975C) was used for the determination of mycotoxins DON, HT-2 and T-2. The mycotoxins DON, HT- 2 and T- 2 were analysed according to the trichothecene analysis method by Saastamoinen and Saloniemi (1997). The detection threshold for each mycotoxin was $21.0 \pm 0.5 \mu \mathrm{g} \mathrm{kg}^{-1}$. Three replicate injections were taken from each variant for mycotoxin analysis.

\subsection{The weather conditions}

The air temperature, sum of precipitation and day of rainfall data were recorded by the weather station of the field experiments in Saku (Table 1).

\subsection{The statistical analyses}

Two factorial ANOVA was used for 2012-2014 field experiments data evaluation. Because the results strongly varied between the years, we used Tukey-Kramer Honest Significant Difference (HSD) test separately in each trial year. Average yield, 1000 kernel weight (four replicate plots per treatment), incidence of Fusarium spp. (the percentage of infected kernels, three replicates per treatment) and concentrations of mycotoxins DON, HT-2 and T-2 (three replicates per treatment) were calculated for each treatment and study year. The concentrations of toxins T2 and HT2 were summarized since toxin T2 is metabolized to toxin HT2, and co-occurs in the grains (Nathanail et al., 2015; Hjelkrem et al., 2018). In all statistical tests, the level of significance was $p<0.05$.

\section{Results}

\subsection{The weather in experimental years}

The weather conditions during the three years of study were extremely different (Table 1). During the 2012 growing season the weather was rainy and cool compared to the long term average weather conditions (Table 1). With a lot of precipitation in June (83.6 mm), July (128.0 mm) and August (103.0 mm), the total amount of precipitation was $42-47 \%$ higher than the long-term average $(57,90$ and $73 \mathrm{~mm}$, respectively). Overall, the weather conditions in 2013 were hot and dry, but August, when barley matured, was very rainy $(110.0 \mathrm{~mm}$ ) (Table 1$)$. In 2014, the air temperatures and the amount of precipitation varied each month. June was cool $\left(12.5^{\circ} \mathrm{C}\right)$ and wet $(81.4 \mathrm{~mm})$. Thereafter, July was hot $\left(19.0^{\circ} \mathrm{C}\right)$ and dry $(42.8 \mathrm{~mm}), \mathrm{Au}-$ gust hot $\left(16.5^{\circ} \mathrm{C}\right)$ with normal precipitation (Table 1$)$. The results of our study showed that compared to 2013 and 2014 , the rainy weather and low temperatures during the growing period in 2012 (Table 1) favoured grain contamination with mycotoxins DON and HT2+T2 in all trial variants (Table 4). At the same time, the average barley grain infestation with Fusarium spp. was low (3.8\%) (Table 3). In 2013, dry and warm growing season combined with rainy and warm weather during maturation (Table 1) was favourable for contamination with the mycotoxin DON in barley grain in all trial variants (Tabel 4) and average incidence of Fusarium spp. was $15.3 \%$ (Table 3). In the warmth and normal precipitation levels of 2014 (Table 1) we detected mycotoxins DON, HT2 and T2 in both untreat- 
ed and tebuconazole variants of barley grain (Table 4) and the average incidence of Fusarium spp. in barley grain was 10.9\% (Table 3).

\subsection{The yield of spring barley and 1000 kernel weight}

The average three-year barley yield was $3058 \mathrm{~kg} \mathrm{ha}^{-1}$ (Table 2), but varied between growing years from
$898 \mathrm{~kg} \mathrm{ha}^{-1}$ in 2012 to $4286 \mathrm{~kg} \mathrm{ha}^{-1}$ in $2014(p<0.05)$. The highest average yield was achieved by untreated control (3 $224 \mathrm{~kg} \mathrm{ha}^{-1}$ ) and the lowest in plots treated with fenpropidin and protioconazole (2 $971 \mathrm{~kg} \mathrm{ha}^{-1}$ ), but these differences between the average yields for three years were not significant due to large variability that resulted from the exceptionally low yield in 2012

Table 1 The weather conditions in the Saku experimental area, North-Estonia in 2012-2014

\begin{tabular}{|c|c|c|c|c|c|c|c|c|c|c|c|c|}
\hline \multirow[b]{2}{*}{ Month } & \multirow[b]{2}{*}{ Decade } & \multicolumn{4}{|c|}{ Air Temperature ( ${ }^{\mathrm{C}}$ ) } & \multicolumn{4}{|c|}{ Precipitation (mm) } & \multicolumn{3}{|c|}{ Number of rain days } \\
\hline & & 2012 & 2013 & 2014 & $\begin{array}{l}\text { Long-term } \\
\text { average }\end{array}$ & 2012 & 2013 & 2014 & $\begin{array}{l}\text { Long-term } \\
\text { average }\end{array}$ & 2012 & 2013 & 2014 \\
\hline \multirow{4}{*}{ May } & I & 8 & 10 & 5.3 & & 20.6 & 0 & 22.2 & & 4 & 0 & 6 \\
\hline & II & 10.2 & 13.5 & 11.9 & & 30.8 & 28.6 & 12.8 & & 5 & 3 & 5 \\
\hline & III & 11.8 & 14.7 & 14.4 & & 5.8 & 33.8 & 8.6 & & 3 & 8 & 5 \\
\hline & & 10.1 & 12.8 & 10.7 & 9.7 & 57.2 & 62.4 & 43.6 & 49.0 & 12 & 11 & 16 \\
\hline \multirow{4}{*}{ June } & 1 & 9.7 & 17.3 & 15.2 & & 27.2 & 4.2 & 17.2 & & 5 & 2 & 4 \\
\hline & II & 13.2 & 14.1 & 11.7 & & 18.0 & 23.4 & 30.2 & & 4 & 2 & 8 \\
\hline & III & 12.8 & 18.7 & 10.7 & & 38.4 & 12.6 & 34.0 & & 7 & 1 & 5 \\
\hline & & 11.9 & 16.7 & 12.5 & 14.5 & 83.6 & 40.2 & 81.4 & 57.0 & 16 & 5 & 17 \\
\hline \multirow{4}{*}{ July } & 1 & 18.1 & 16.8 & 17.2 & & 16.8 & 23.2 & 34.8 & & 2 & 3 & 5 \\
\hline & II & 14.6 & 16.3 & 18 & & 87.2 & 6.8 & 3.0 & & 6 & 3 & 2 \\
\hline & III & 17.9 & 18 & 21.6 & & 23.6 & 11.6 & 5.0 & & 6 & 3 & 3 \\
\hline & & 16.9 & 17.1 & 19.0 & 16.3 & 128 & 41.6 & 42.8 & 90.0 & 14 & 9 & 10 \\
\hline \multirow{4}{*}{ August } & 1 & 15.3 & 18.4 & 20.6 & & 34.4 & 55 & 8.6 & & 7 & 4 & 2 \\
\hline & II & 14.1 & 16 & 16.4 & & 26.4 & 49.8 & 8.0 & & 2 & 7 & 9 \\
\hline & III & 13.1 & 14.8 & 12.9 & & 42.6 & 5.2 & 52.0 & & 8 & 2 & 7 \\
\hline & & 14.1 & 16.3 & 16.5 & 15.3 & 103.0 & 110.0 & 68.6 & 73.0 & 17 & 13 & 18 \\
\hline \multicolumn{2}{|c|}{ Average/Total } & 13.2 & 15.7 & 14.7 & 14.0 & 372.0 & 254.0 & 236.0 & 269.0 & 59 & 38 & 61 \\
\hline
\end{tabular}

Long-term average values refer to the time period 1980-2010.

Table 2 The yield and 1000 kernel weight in spring barley in 2012-2014

\begin{tabular}{|c|c|c|c|c|}
\hline Treatment & 2012 & 2013 & 2014 & Mean \\
\hline \multicolumn{5}{|l|}{ Yield, kg ha-1 } \\
\hline Untreated & $765^{\mathrm{cb}}$ & $4167^{\mathrm{Ba}}$ & $4740^{\text {Aa }}$ & $3224^{a}$ \\
\hline Tebuconazole (Folicur, $1.0 \mathrm{I} \mathrm{ha}^{-1}$ ) & $1097^{\text {Ва }}$ & $4198^{\mathrm{Aa}}$ & $3848^{\mathrm{Aa}}$ & $3048^{\mathrm{a}}$ \\
\hline Protioconazole, tebuconazole, spiroxamine (Falcon Forte $1.0 \mathrm{I} \mathrm{ha}^{-1}$ ) & $904^{\text {Bab }}$ & $3738^{\text {Aa }}$ & $4319^{\text {Aa }}$ & $2987^{a}$ \\
\hline Fenpropidin, propiconazole (Archer Top $0.8 \mid \mathrm{ha}^{-1}$ ) & $826^{\mathrm{Bab}}$ & $3853^{\text {Aa }}$ & $4235^{\text {Aa }}$ & $2971^{\mathrm{a}}$ \\
\hline Mean & $898^{8}$ & $3989^{A}$ & $4286^{A}$ & \\
\hline \multicolumn{5}{|l|}{1000 kernel weight $(\mathrm{g})$} \\
\hline Untreated & $27.0^{\mathrm{cb}}$ & $45.7^{\mathrm{Ab}}$ & $43.6^{\mathrm{Bb}}$ & $38.8^{\mathrm{a}}$ \\
\hline Tebuconazole (Folicur, $1.0 \mathrm{I} \mathrm{ha}^{-1}$ ) & $28.8^{\mathrm{Ca}}$ & $47.9^{\mathrm{Aa}}$ & $44.9^{\text {ва }}$ & $40.5^{\mathrm{a}}$ \\
\hline Protioconazole, tebuconazole, spiroxamine (Falcon Forte $1.0 \mathrm{I} \mathrm{ha}^{-1}$ ) & $29.5^{\mathrm{Ba}}$ & $46.1^{\mathrm{Ab}}$ & $45.5^{\mathrm{Aa}}$ & $40.4^{\mathrm{a}}$ \\
\hline Fenpropidin, propiconazole (Archer Top $0.8 \mathrm{I} \mathrm{ha-1)}$ & $28.8^{\mathrm{Ca}}$ & $46.3^{\mathrm{Ab}}$ & $43.6^{\mathrm{Bb}}$ & $39.5^{\mathrm{a}}$ \\
\hline Mean & $28.5^{\mathrm{C}}$ & $46.5^{\mathrm{A}}$ & $44.4^{\mathrm{B}}$ & \\
\hline
\end{tabular}

The data were compared by ANOVA followed by HSD test. Different uppercase letters show statistically significant $(\mathrm{p}<0.05)$ difference among study years within the treatments and different lowercase letters show significant differences among treatments within studed years. 
Table 3 The incidence (\%) of Fusarium spp. in barley kernels in 2012-2014

\begin{tabular}{|c|c|c|c|c|}
\hline Treatment & 2012 & 2013 & 2014 & Mean \\
\hline Untreated & $3.0 \mathrm{~A}^{\mathrm{a}}$ & $14.0^{\mathrm{Aa}}$ & $6.0^{\mathrm{Aa}}$ & $7.7^{\mathrm{b}}$ \\
\hline Tebuconazole (Folicur 1.0) & $5.0^{\mathrm{Aa}}$ & $19.0^{\mathrm{Aa}}$ & $24.8^{\mathrm{Aa}}$ & $16.3^{a}$ \\
\hline Prothioconazole, tebuconazole, spiroxamine (Falcon Forte 1.0) & $4.0^{\mathrm{Aa}}$ & 24.1 Aa $^{\text {a }}$ & $8.0^{\mathrm{Aa}}$ & $12.0^{\mathrm{a}}$ \\
\hline Fenpropidin, propiconazole (Archer Top 0.8) & $3.0^{\mathrm{Aa}}$ & $4.0^{\mathrm{Ab}}$ & $5.0^{\mathrm{Ab}}$ & $4.0^{c}$ \\
\hline Mean & $3.8^{B}$ & $15.3^{\mathrm{A}}$ & $10.9^{\mathrm{AB}}$ & \\
\hline
\end{tabular}

The data were compared by ANOVA followed by HSD test. Different uppercase letters show statistically significant $(\mathrm{p}<0.05)$ differences among study years within the treatments and different lowercase letters show significant differences among treatments within studed years.

Table 4 Effects of fungicides and year on the DON, HT-2 and T-2 mycotoxins content $\mu \mathrm{g} \mathrm{kg}^{-1}$ in barley kernels in 2012-2014

\begin{tabular}{|c|c|c|c|}
\hline & \multicolumn{3}{|c|}{ DON $\mu \mathrm{g} \mathrm{kg}^{-1}$} \\
\hline Treatment & 2012 & 2013 & 2014 \\
\hline Untreated & 73.3a & $63.0^{\circ}$ & $65.5^{\mathrm{a}}$ \\
\hline Tebuconazole (Folicur 1.0) & $66.0^{\mathrm{b}}$ & $63.0^{\mathrm{bc}}$ & $64.8^{\mathrm{a}}$ \\
\hline Prothioconazole, tebuconazole, spiroxamine (Falcon Forte 1.0) & $69.7^{\mathrm{ab}}$ & $63.1^{\mathrm{a}}$ & $0.0^{\mathrm{b}}$ \\
\hline Fenpropidin, propiconazole (Archer Top 0.8) & $66.0^{\mathrm{b}}$ & 63.1ab & $0.0^{\mathrm{b}}$ \\
\hline \multirow[t]{2}{*}{ Pvalue } & 0.001 & 0.009 & $<0.001$ \\
\hline & \multicolumn{3}{|c|}{$\mathrm{HT}-2$ and $\mathrm{T}-2, \mu \mathrm{gg}^{-1}$} \\
\hline Untreated & $27.5^{\mathrm{b}}$ & $0.0^{\mathrm{a}}$ & $32.9^{\mathrm{a}}$ \\
\hline Tebuconazole (Folicur 1.0) & $26.2^{\mathrm{bc}}$ & $0.0^{\mathrm{a}}$ & $32.6^{\mathrm{a}}$ \\
\hline Prothioconazole, tebuconazole, spiroxamine (Falcon Forte 1.0) & $25.6^{\mathrm{c}}$ & $0.0^{\mathrm{a}}$ & $0.0^{\mathrm{b}}$ \\
\hline Fenpropidin, propiconazole (Archer Top 0.8) & $62.3^{\mathrm{a}}$ & $0.0^{\mathrm{a}}$ & $0.0^{\mathrm{b}}$ \\
\hline Pvalue & $<0.001$ & ns & $<0.001$ \\
\hline Factor & \multicolumn{2}{|l|}{ DON } & HT-2 and T-2 \\
\hline Year & \multicolumn{2}{|l|}{0.001} & $<0.001$ \\
\hline Treatment & \multicolumn{2}{|l|}{ ns } & ns \\
\hline Year*Treatment & \multicolumn{2}{|l|}{$<0.001$} & $<0.001$ \\
\hline
\end{tabular}

Different letters behind the mean values $(n=3)$ indicate significant differences $(p<0.05)$ in a category.

(Table 2). The highest barley yield compared to the untreated control, $1097 \mathrm{~kg} \mathrm{ha}^{-1}$, was obtained in 2012 in tebuconazole treated plots $(p<0.05)$ (Table 2$)$. No differences in yield among other treatments were observed in 2012 and 2013 (Table 2). The highest yield of barley was obtained in 2014, however the yield in control and treated plots was not significantly different. The overall average 1000 kernel weight was 39.8 grams, lowest $(p<0.05)$ in 2012 (28.5 grams) and highest in 2013, (46.5 grams) (Table 2). The highest average 1000 kernel weight in the three years was found in the variant of tebuconazole (40.5 g) and lowest in the variant of untreated control (38.8 g). As the three-year average results among treatments were not significantly different, the treatment with fungicides had no effect on the 1000 kernel weight (Table 2).

\subsection{Incidence of Fusarium spp. and mycotoxins DON, HT-2 and T-2}

The three-year incidence of Fusarium spp. was on average $10.0 \%$ (Table 3). The impact of year together with fungicide treatment had a significant effect on the incidence of Fusarium spp. $(p<0.05)$ (Table 3$)$ and on the incidence of mycotoxins (Table 4$)$ in barley kernels $(p<0.001)$.The incidence of Fusarium spp. in barley grain was lowest in 2012 and highest in 2013 (Table 3). In 2012, Fusarium spp. was present on average in $3.8 \%$ of grains (Table 3). In 2013, the incidence of Fusarium spp. was on average $15.3 \%$, whereas $14.0 \%$ of barley grain in the untreated variant was contaminated with Fusarium fungi (Table 3). The incidence of Fusarium spp. in the variants with tebuconazole or a commercial mixture of three active ingredients (prothioconazole, tebuconazole, spiroxamine) was $19.0 \%$ and $24.1 \%$, respectively. The lowest incidence 
of Fusarium spp. of only $4 \%$ of barley kernels, was found in the commercial mix of active ingredients phenpropidin and propiconazole (Table 3). In 2013 and 2014, spraying with fungicides reduced $(p<0.05)$ the incidence of Fusarium spp. in grains from plants treated with the commercial mix of active ingredients phenpropidin and propiconazole variants, where the incidence of Fusarium spp. was only $4 \%$ and $5 \%$, respectively (Table 3 ). The concentration of mycotoxins DON, HT-2 and T-2 in barley kernels was low during the study. The year effects varied for different treatments for different mycotoxins (Table 4). Mycotoxin DON was detected in all trial variants of barley in 2012 and 2013 and in untreated and tebuconazole variants in 2014. HT2+T2 toxins were present in all variants in 2012 and in the untreated and tebuconazole variants in 2014 (Table 4). In 2012, concentration of the mycotoxin DON was highest $(p=0.001)$ in the untreated variant (73.3 $\mu \mathrm{g} \mathrm{kg}^{-1}$ barley grain), compared with the treated variants (Table 4). Higher DON levels were also present in barley kernels treated by the commercial mix of three active ingredients prothioconazole, tebuconazole and spiroxamine (69.7 $\left.\mu \mathrm{g} \mathrm{kg}^{-1}\right)$ compared to barley from the tebuconazole or the commercial mix of fenpropidin and propiconazole variants. In 2012, DON concentrations were significantly lower $(p=0.001)$ in the variants with tebuconazole and with a commercial mix of active ingredients fenpropidin and propiconazole (Table 4). In 2012, mycotoxins HT2+T2 were detected in all trial variants and their concentration was significantly higher $\left(62.3 \mu \mathrm{g} \mathrm{kg}^{-1}\right)(p=0.001)$ in the variant with the commercial mix of active ingredients fenpropidin and propiconazole (Table 4). The lowest HT2+T2 content (25.6 $\mu \mathrm{g} \mathrm{kg}^{-1}$ ) $(p<0.05)$ was found in barley variant treated by the commercial mixture of three active ingredients (prothioconazole, tebuconazole and spiroxamine) (Table 4).

In 2013 the mycotoxin DON was detected in all trial variants of barley (Table 4). The highest DON content, $63.1 \mu \mathrm{g} \mathrm{kg}^{-1}$, was found in barley treated with commercial mix of three active ingredients protioconazole, tebuconazole, spiroxamine and the lowest in barley from untreated variant (63.0 $\left.\mu \mathrm{g} \mathrm{kg}^{-1}\right)(p=0.009)$ (Table 4). In 2013, mycotoxins HT2+T2 were not detected in barley (Table 4).

In 2014 the mycotoxin DON was present only in untreated (65.5 $\mu \mathrm{g} \mathrm{kg}^{-1}$ ) and tebuconazole-sprayed $\left(64.8 \mu \mathrm{g} \mathrm{kg}^{-1}\right)$ variants $(p<0.001)$ (Table 4). Mycotoxins HT2+T2 were similarly detected only in the untreated (32.9 $\mu \mathrm{g} \mathrm{g}^{-1}$ ) and tebuconazole (32.6 $\mu \mathrm{g} \mathrm{kg}^{-1}$ ) variants, but not in the barley treated by the commercial mix of three active ingredients prothioconazole, tebuconazole and spiroxamine or by the commercial mix of the active ingredients fenpropidin and propiconazole $(p<0.001)$ (Table 4).

\section{Discussion}

In a three-year field experiment,we studied the effect of fungicide application at flowering time in spring barley on the yield, 1000 kernel weight, incidence of Fusarium fungi and mycotoxins DON, HT-2 and T-2. The results of our study showed that the yield and 1000 kernel weight of spring barley were similar in most fungicide treatments and in untreated control in years with a high barley yield, but not in the year with a low yield. Also, the spraying with fungicides had not a clear effect on the barley yield and 1000 kernel weight, and primarily the study year was the main factor that affected barley yield and 1000 kernel weight. As in our study, Stetkiewicz et al., (2019) also concluded that application of fungicide had no effect on barley yield. From the long-term field trials, the application of fungicides resulted in a significant yield increase in only 35\% of cases (Stetkiewicz et al., 2019). On the other hand, in other field trials with spring barley it was shown that the impact of year had a stronger influence on the plant diseases; and spraying of more resistant varieties with fungicides at late growth stage decreased the yield (Sooväli and Koppel, 2009). In field trials designed to compare single to double application of fungicides, the highest yield and 1000 kernel weight were achieved after a double fungicide application (Caldwell et al., 2017). In our trials the barley heads were treated with fungicide only once at the flowering time, and the non-significant effect of fungicides in highyield years might indicate that one treatment was not enough to get the highest yield and 1000 kernel weight.

In our study, differences in weather among different study years had a stronger influence on the incidence of Fusarium spp. on kernels compared to the effect of fungicides. The effect of treatment with fungicides varied between the years, and only the fungicide with two active ingredients (fenpropidin and propiconazole) was found to decrease the incidence of Fusarium spp. in barley. Analogous equivocal results have been observed in other studies. In Lithuanian field trials, the commercial mixture of protioconazole and tebuconazole effectively decreased Fusarium spp. contamination in barley kernels (Semaškiene et al. 2006). In addition, in accordance with our results, it turned out that the weather had a strong impact to the efficiency of fungicides on Fusarium spp. (Semaškiene et al., 2006). Unlike our study and that of Semaškiene et al. (2006), several other studies have demonstrated that single fungicides, e.g. tebuconazole, are effective in controlling Fusarium incidence. The active ingredients of fungicides may also have a positive impact on the incidence of Fusarium spp. in cereal grain (Gaurilčikienè et al., 2011). We did not find a similar eff- 
fect. However, the results of two study years showed that for tebuconazole and for the commercial mix of prothioconazole, tebuconazole and spiroxamine the incidence of Fusarium spp. was higher in the barley grain compared to samples that were untreated or treated with the commercial mix containing fenpropidin and propiconazole. Some studies found that various ingredients of fungicides may support the production of trichothecenes by Fusarium spp. in wheat (Giraud et al., 2011), also in rye and triticale kernels (Gaurilčikienè et al., 2011). In our study the levels of mycotoxins DON, HT-2 and T-2 in barley kernels varied from year to year and the application of the fungicides showed a variable effect. Mycotoxin DON was detected in barley kernels in all years, but it occurred only in untreated and tebuconazole-treated variants in 2014. Mycotoxins HT2 + T2 were found in barley grains in all variants in 2012, but only in untreated and tebuconazole-treated variant in 2014. The weather conditions have a strong impact on the incidence of mycotoxins in barely grain. Although the trend showed that the treatment with fungicides reduced the mycotoxin DON in barley grain, the effect of active ingredients on mycotoxin DON in barley was not clear. The efficiency of fungicides in decreasing mycotoxin HT2 and T2 in barley grain was not demonstrated. Similarly, the field trials conducted in the Czech Republic over four years with spring barley revealed, that the mycotoxin content in kernels varied between the years, but the combination of the active fungicide ingredients decreased the accumulation of DON (Váňova et al., 2004). In France, it was also found that in naturally infected conditions in winter barley during three experimental years the average DON content was very low $\left(<20 \mu \mathrm{g} \mathrm{kg}^{-1}\right)$ and the fungicide treatment had an indistinct effect on Fusarium infection (Ioos et al., 2005). In our study, the concentration of mycotoxins was also low. Ioos et al., (2005) concluded that in the first experimental year, better effect was achieved using a complex fungicide containing a mixture of active ingredients. In the second year, six single ingredient fungicides had better effect and in the third experimental year, only one fungicide was effective against Fusarium spp. Moreover, the treatment with fungicides had no effect on the accumulation of DON and NIV (Ioos et al., 2005). The study of Malachova et al., (2010) with several varieties of brewery barley found that $86 \%$ of samples were contaminated with DON and $62 \%$ of samples with HT-2. Nevertheless, weather had the strongest impact on the occurrence of mycotoxins (Malachova et al., 2010). Běláková et al., (2014), based on a four-year study with malting barley, also concluded, that the weather influenced the contamination of kernels with mycotoxins. The results of our experiments in field conditions con- firm that fungicides were not clearly effective in reducing the content of mycotoxins DON, HT- 2 and T-2 in barley grain, because the impact of weather was stronger. Many researchers have found that weather conditions during heading, flowering and ripening time of cereals affected the incidence of Fusarium and mycotoxins in cereal kernels; heavy rainfall during these growth stages favoured the incidence of Fusarium spp. and mycotoxins in grain (Mankevičiene et al., 2011). In the Estonian climate, the flowering, development of kernels and ripening of spring cereals occur from July to the beginning of September. In this study the weather conditions of heading, flowering and ripening stages varied year by year. However, it is in these growth stages that the Fusarium spp. infected the heads of cereals and started to produce mycotoxins (Osborne and Stein, 2007; Burlakoti et al., 2011). Edwards (2009) found that weather conditions during the growing season influenced significantly the contamination of barley grain with mycotoxins. The occurrence of different mycotoxins such as DON, 3-ADON, 15-ADON, HT-2, T-2 and fusarenoon X, varied between the years (Edwards, 2009). The concentrations of the mycotoxin DON in our study were lower than the maximal limits allowed by the European Commission legislation (1 $250 \mu \mathrm{g} \mathrm{kg}^{-1}$, EC 1881/2006). In earlier research it was declared that the mycotoxin DON occurred most frequently in barley grain in Europe, Scandinavian and North-America, being found in 58-91\% of samples, mycotoxin HT-2 was found in $12-50 \%$ of barley samples and mycotoxin T-2 was detected in 58-91\% of barley samples. The average concentration of DON in Europe is $189 \mu \mathrm{g} \mathrm{kg}^{-1}$ and in Scandinavian barley it is $229 \mu \mathrm{g} \mathrm{kg}^{-1}$ (Petterson, 1996; Perkowski et al., 2003).

\section{Conclusions}

A single treatment of spring barley crop with fungicide at flowering time had no effects on the yield and 1000 kernel weight. Three-year average results showed that the effectiveness of fungicides to reduce Fusarium fungi and to prevent the grain contamination with mycotoxins varied from year to year. The treatment of spring barley with a fungicide containing a commercial mix of active ingredients fenpropidin and propioconazole decreased the incidence of Fusarium spp. in grain. The content of mycotoxins DON, HT2 and T2 in barley grain was influenced by the interactions of the weather during the growing season and depended on the active ingredients of the fungicides. Hence, we suggest that the use of fungicides is not economically viable to decrease the content of mycotoxins in grains. 


\section{Acknowledgements}

The study was supported by Estonian Ministry of Rural Affairs in the project „Identification of less known toxins producing moulds, the conditions for occurrence and prevention of hazards in Estonian spring barley“, the European Regional Development Fund (the Center of Excellence EcolChange: Ecology of global change: natural and managed ecosystems) and the Estonian University of Life Sciences base funding projects P190259PKTT and P180273PKTT. We thank Ene Ilumäe for help in conducting the field trials.

\section{References}

Baik, B-K., Ullrich, S.E. (2008). Barley for food: Characteristics, improvement, and renewed interest. Journal of Cereal Science, 48, 233-242. https://doi.org/10.1016/j.jcs.2008.02.002

Bĕláková, S., Benešová, K., Čáslavský, J., Svoboda, Z. (2014). The occurrence of the selected Fusarium mycotoxins in Czech malting barley. Food Control, 37, 93-98. https://doi.org/ 10.1016/j.foodcont.2013.09.033

Burlakoti, R. R., Neate, S. M., Adhikari, T. B., Gyawali, S., Salas, B., Steffenson, B. J., and Schwarz, P. B. (2011). Trichothecene profiling and population genetic analysis of Gibberella zeae from barley in North Dakota and Minnesota. Phytopathology 101, 687-695. https://doi. org/ 10.1094/PHYTO-04-10-0101

Caldwell, C.D., MacDonals, D., Jiang, Y., Cheema, M.A., Li, J. (2017). Effects of fungicide combinations for Fusarium head blight control on disease incidence, grain yield, and quality of inter wheat, spring wheat and barley. Canadian Journal of Plant Science 97, 1036-1045. https:// doi.org/10.1139/cjps-2017-0001

Edwards, S. G. (2009). Fusarium mycotoxin content of UK organic and conventional barley. Food Additives and Contaminants, 26 (8), 11851190. https://doi.org/10.1080/02652030902919418

Gaurilčikienè, I., Mankevičienè, A., Suproniene, S. (2011). The effect of fungicides on rye and triticale grain contamination with Fusarium fungi and mycotoxins. Žemdirbyste - Agriculture, 98, 19-26.

Giraud. F., Pasquali, M., el Jarroudi, M., Cocco, M., Delfosse, P., Hoffmann, L., Bohn, T. (2011). Timely fungicide application: A strategy to minimize Fusarium head blight and associated mycotoxin production in winter wheats. Journal of Plant Pathology, 93, 15-18. https://doi.org/ 10.4454/jpp.v93i1sup.1214

Hietaniemi, V., Rämö, S., Yli-Mattila, T., Jestoi, M., Peltonen, S., Kartio, M., Sieviläinen, E., Koivisto, T., Parikka, P. (2016). Updated survey of Fusarium species and toxins in Finnish cereal grains. Food Additives \& Contaminants: Part A, 33 (5), 831-848. https://doi.org/10.1080/ 19440049.2016.1162112

Hjelkrem, A.R., Aamost, U.A., Brodal,G., Strand,E.C., Trop,T.,Edwards,S.G., Dill-Mckey,R., Hoofgaard, I.S. (2018). HT2 and T2 toxins in Norwegian oat grains related to weather conditions at different growth stages. European Journal of Plant Pathology, 151, 501-514. https:// doi.org/10.1007/s10658-017-1394-3

Horky, P., Skalicova, S., Caslavova, I., Deering, A. J., Nevrkla, P., Slama, P., Trojan, V., Skladanka, J. (2018): Effect of fungicidal treatment and storage conditions on content of selected mycotoxin in barley. Kvasny Prumysl, 64 (5), 212-216. https://doi.org/ 10.18832/ kp201827
Ioos, R., Belhadj, A., Menez, M., Faure, A. (2005). The effect of fungicides in Fusarium spp. and Microdochiumnivale and their associated trichothecene mycotoxins in French naturally infected cereal grains. Crop Protection, 24, 894-902. https://doi.org/10.1016/j.cropro.2005.01.014

Leslie, J. F., Summerell, B. A. (2006). The Fusarium Laboratory Manual. Blackwell Publishing, 388.

Lõiveke, H., Laitamm, H., Sarand, R.-J. (2003). Fusarium fungi as potential toxicants on cereals and grain feed grown in Estonia during 1973-2001. Agronomy Research, 1(2), 185-196. https://www. etis.ee/Portal/Publications/Display/8490bde4-d388-4b39-b63879a8358dd9f6

Lõiveke, H. (2004). The effect of fungicides on the microflora of grains. Latvian Journal of Agronomy, 7: Epidemiology facets of harmful organisms in cropping systems, Jelgava, Latvia, August 26-28. Ed. Bankina,B.; Brazauskiene,I.; Lapins,D.;Lõivek,H.; Luik,A.; Rashal,I.; Semaskiene,R.; Sigvald,R.; Stan. Jelgava: Latvia University of Agriculture, 115-118. https://www.etis.ee/Portal/Publications/Display/0b3ad12f-1978-487d-a131-cd844a64fe0d

Lõiveke, H., Ilumäe, E., Akk, E. (2008). Teravilja mikrobioloogiast ja ohutusest. Agraarteadus, XIX(2), 38-45. https://www.etis.ee/Portal/ Publications/Display/f4d8153f-c59f-4c76-bd66-1ab6dceecc35

Malachova, A., Cerkal, R., Ehrenbergerova, J., Dzuman, Z., Vaculova, K., Hajslova, J. (2010). Fusarium mycotoxins in various barley cultivars and their transfer into malt. Journal of the Science of Food and Agriculture, 90, 2495-2505. https://doi.org/ 10.1002/jsfa.4112

Mankevičiene, A., Butkuti, B., Gaurilčikiene, I., Dabkevičius, Z., Suproniene, S. (2011). Risk assessment of Fusarium mycotoxins in Lithuania small cereal grains. Food Control, 22, 970-976. https://doi. org/10.1016/j.foodcont.2010.12.004

Mateo, E.M., Valle-Algarra, F.M., Mateo, R., Jiménez, M., Magan, N. (2011). Effect of fenpropimorph, prochloraz and tebuconazole on growth and production of T-2 and HT-2 toxins by Fusarium langsethiae in oat-based medium. Internal Journal of Food Microbiology, 151, 289-298. https://doi.org/10.1016/j.ijfoodmicro.2011.09.017

Nathanail, A.V., Varga, E., Heng-Reiter, J., Bueschl, C., Michlmayr, H., Malachova, A., Fruhmann, P., Jestoi, M., Peltonen, K., Adam, G., Lemmens, M., Schumacher, R., Berthiller, F. (2015). Metabolism of the Fusarium Mycotoxins T-2 Toxin and HT-2 Toxin in Wheat. Journal of Agricultural and Food Chemistry, 63, 7862-7872. https://doi.org/ 10.1021/ acs.jafc.5b02697

Nielsen, L. K., Cook, D. J., Edwards, S., Ray, R. V., 2014: The prevalence and impact of Fusarium head blight pathogens and mycotoxins on malting barley quality in UK. International Journal of Food Microbiology, 179: 38-49. https://doi.org/10.1016/j.ijfoodmicro.2014.03.023

Osborne, L.E., Stein, J.M. (2007). Epidemiology of Fusarium head blight on small-grain cereals. International Journal of Food Microbiology, 119, 103-108. https://doi.org/ 10.1016/j.ijfoodmicro.2007.07.032

Perkowski, J., Kiecana, J., Kaczmasek, Z. (2003). Natural occurrence and distribution of Fusarium toxins in contaminated barley cultivars. European Journal of Plant Pathology, 109, 331-339. https://doi.org/ 10.1023/A:1023547210060

Pettersson, H. (1996). Mycotoxins in Scandinavian cereals. In Proceedings International. III Seminar: Mycotoxins in Food, Raw Materials and Industrial Fodders, Bydgoszcz, 14-20.

Parikka, P., Hakala, K., Tiilikkala, K. (2012). Expected shifts in Fusarium species composition of cereal grain in Northren Europe due to climatic change. Food Additives and Contaminants: Part A, 29 (10), 1543-1555. https://doi.org/10.1080/19440049.2012.680613

Saastamoinen, I. H. Saloniemi, H. (1997). Quantification and confirmation of trichothecenes by gas chromatography - mass spectrometry - selected ion monitoring. $9^{\text {th }}$ Int. Congress in Animal Hygiene ISAH'97, 
17-21 Aug. 1997, Helsinki, Finland.Proceedings v.2, Ed. H. Saloniemi, University of Helsinki, Helsinki 1997, 431-434. https://www.isahsoc.org/userfiles/downloads/proceedings/1997/Volume2.pdf

Semaškiene, R., Mankevičiene, A., Dabkevičius, Z., Suproniene, S. (2006). Effect of fungicides on Fusarium infection and production of deoxynivalenol in spring cereals. Agronomy Research 4 (Special Issue), 363-366. https://pdfs.semanticscholar.org/3acc/4a0020fd444fe935244491d5aa21635e6846.pdf

Sooväli, P. Koppel, M. (2009). Efficacy of fungicide tebuconazole in barley varieties with different resistancelevel.Agricultural and Food Science, 19 (1), 34-42. https://doi.org/ 10.2137/145960610791015069

Sooväli, P., Koppel, M., Kangor, T. (2017). Effectiveness of seed treatment against Fusarium spp. and Cochliobolus sativus of spring barley in different conditions. Agronomy Research, 15 (1), 280-287. https:// doi.org/ 10.15159/AR.17.052

Estonian Statistics, 2016. Resources and usage of agricultural products (in Estonian). Available at: http://pub.stat.ee/px-web.2001/ Dialog/varval.asp? $\mathrm{ma}=\mathrm{PM} 20$ \& $\mathrm{ti}=$ TERAVILJA+RESSURSS+JA+KASUTAMINE+LIIGI+J\%C4RGI\&path=../Database/Majandus/13Pellumajandus/06Pellumajandussaaduste_tootmine/04Pellumajandussaaduste_ressurss_ja_kasutamine/\&lang=2, (accessed on $10 / 03 / 2019$ )

Statistics Estonia, 2019. Agricultural land and cultivated area of crops. Avalaibale at: https://www.stat.ee/34243?highlight=barley\%2Cgrowing\%2Carea\%2C2016-2018 (accessed on 18/03/2019)
Stetkiewicz, S., Burnett, F.J., Ennos, R, A., Topp, C.F.E. (2019). The impact of fungicide treatment and Pest Management on barley yields: Analysis of a long term field trials database. European Journal of Agronomy 105, 111-118. https://doi.org/ 10.1016/j.eja.2019.02.010

Váňova, M., Hajšlova, J., Havlova, P., Matušinski, P., Lancova, K., Spitzerova, D. (2004). Effect of spring barley protection on the production of Fusarium spp. mycotoxins in grain and malt using fungicides in field trials. Plant, Soil and Environment, 50, 447-455. https://doi. org/ 10.17221/4057-PSE

Wegulo, S.N., Baenziger, P.S., Nopsa, J.H., Bockus, W.W., Hallen-Adams, H. (2015). Management of Fusarium head blight of wheat and barley. Crop Protection, 73, 100-107. https://doi.org/ 10.1016/j.cropro.2015.02.025

Yli-Mattila, T., Rämo, S., Tanner, R., Lõiveke, H., Hietaniemi, V. (2011). Fusarium DNA levels as compared with mycotoxin levels in Finnish and Estonian grain samples. Plant Breed and Seed Science, 64, 131140. https://doi.org/ 10.2478/v10129-011-0036-8

Yli-Mattila, T., Rämo, S., Hussien, T., Carlobos-Lopez, AL, Cumagun, CJR. (2013). Molecular quantification and genetic diversity of toxigenic Fusarium species in northern Europe as compared with those in southern Europe. Microorganisms, 1, 162-174. https://doi.org/ 10.3390/microorganisms1010162 